\title{
CHANGES IN FUNCTIONAL RESIDUAL CAPACITY DURING RESPIRATORY FAILURE
}

\author{
P. R. RamachandRan, M.B., B.S., F.R.C.P.(c), AND \\ H. B. FAIRLEY, M.B., B.S., F.F.A.R.C.S. ${ }^{*}$
}

ACCURATE RESPIRATORY FAILURE is frequently characterized by an enlarged alveolar-arterial oxygen difference $\left(\mathrm{AaDO}_{2}\right)$ as a result of the perfusion of non-ventilated alveoli ${ }^{1-3}$ through accumulation of secretions, inflammatory consolidation, oedema, or atelectasis. Therapy is, in part, aimed at restoring ventilation of these areas by manoeuvres such as intermittent positive pressure ventilation with large tidal volumes, chest physiotherapy, and tracheobronchial toilet.

The alveolar-arterial oxygen difference is, however, a non-linear function and is influenced by many factors other than the number of non-ventilating alveoli. A completely reliable estimate of the latter is not available, although changes in pulmonary compliance have been shown experimentally to be a sensitive test., ${ }^{4, \tilde{0}}$ However, the need to pass an oesophageal balloon precludes the use of this measurement on a day-to-day basis, and consequently consideration has been given to the usefulness of lung volume measurements. ${ }^{6}$

This study was designed to determine the magnitude of the functional residual capacity (FRC) in patients with respiratory failure, and to define the relationship of this variable to $\mathrm{AaDo}_{2}$. Further, since recumbency ${ }^{7-9}$ and oxygen breathing may themselves cause a reduction in FRC and contribute to the results obtained, a study was designed to examine the effects of these factors in normal adults.

\section{METHODS}

The FRC was measured by a helium dilution method employing a catharometer and a spirometer. ${ }^{10-13}$ A self-inflating bag and a suitable valving system ${ }^{13}$ were employed in the circuit during controlled ventilation. Corrections were made for errors arising from starting at a point other than end-expiration and from the changes in the oxygen concentration used during the measurement on the catharometer reading. In intubated or tracheostomized patients a volume equal in millilitres to a third of the body weight in pounds was added to the measured FRC. The volumes were corrected to BTPS. In each instance, measurements were made in duplicate, and mean values are quoted. The mean difference between duplicate values was $110 \mathrm{ml}$ (s.D. \pm 73 ).

A gas-tight two-way tap, with a $15 \mathrm{ml}$ dead space, was designed to permit easy connection of the patient to the FRC apparatus during both spontaneous and controlled ventilation. By monitoring the airway pressure it was possible to connect the patient to the spirometer at any desired pressure. This facilitated measure-

-Department of Anaesthesia, University of Toronto and Toronto General Hospital. 
ment of FRC during the application of the negative phase or a positive pressure hold at the end of expiration.

Arterial blood was analysed for $\mathrm{pH}, \mathrm{Pco}_{2}$ and $\mathrm{Po}_{2}$ at $37^{\circ} \mathrm{c}$, using an Instrumentation Laboratory $\mathrm{pH} /$ gas analyser. Inspired oxygen concentration was analysed on a Beckman model $\mathrm{E} 2$ oxygen analyser, whose accuracy had been checked with Scholandered gas mixtures.

In spontaneously breathing subjects on 100 per cent inspired oxygen, the inspired oxygen tension $\left(\mathrm{PI}_{\mathrm{O}_{2}}\right)$ was considered to be the same as the dry barometric pressure. During controlled ventilation, the inspired gas was sampled when the ventilator dials were set to deliver 100 per cent oxygen. The inspired oxygen tension was determined from this concentration and the dry barometric pressure. The alveolar oxygen tension was calculated assuming a gas exchange ratio of 1:1.

\section{FRC and $\mathrm{AaDo}_{2}$ during respiratory failure}

Measurements were made in 12 patients in the supine position and were repeated at intervals during the period of respiratory failure. The initial spirometer oxygen concentration was adjusted to approximate that of the patient's inspired air immediately before the start of each measurement. A sample of arterial blood was withdrawn and the FRC was measured, first after twenty minutes of ventilation at the clinically indicated oxygen concentration ( $\mathrm{CrOC}$ ) and then at 100 per cent oxygen. The CIOC is the actual oxygen concentration which the patient had been receiving prior to the study. This is not accurately measured in patients on pressure constant ventilators ${ }^{14}$ or when the inspired air is supplemented with oxygen during spontaneous ventilation, as when using an Edinburgh mask. In all such cases measurements at the cror were omitted.

In the two patients with emphysema and respiratory failure, the approximate croc was determined by using a mixing chamber for inspired gas. The Edinburgh mask which was used to supplement the inspired air with oxygen was positioned at the distal end of the mixing chamber. The gas was mixed in the chamber and delivered to the patient through a Hans-Rudolph valve. Determinations of FRC were made of these approximate inspired oxygen concentrations.

\section{Measurements of FRC in normal subjects}

The following studies were carried out in normal volunteers who did not have a history of cardio-pulmonary disease.

(a) Effect of changing from sitting to supine position.

(b) Effect of several hours of recumbency. FRC was first measured in the sitting position. Measurements were repeated immediately after assuming the recumbent position and then at hourly intervals for four hours.

(c) Effect of breathing air, 50 per cent oxygen, 75 per cent oxygen, and 100 per cent oxygen for twenty minutes in the supine position. The subjects were asked to sit up and take five breaths to total lung capacity ( ILC) before each change in inspired gas mixture.

In order to establish a basis for comparison, each study $(a, b, c)$ was preceded by having the subject take five breaths to TLC and then exhale to FRC. 


\section{RESULTS}

The results are presented in Tables I to $\mathrm{V}$ and Figures 1 to 3.

FRC in normal subjects

A large fall in FRC was observed on the subjects assuming the recumbent position (Table III). Subjects recumbent for up to four hours did not demonstrate any further fall during this period (Table IV).

Oxygen breathing caused a reduction in FRC in supine subjects (Table V). This was not usually large, and was not observed when the inspired gas mixture contained 50 per cent or 75 per cent oxygen.

TABLE I

Diagnoses of Patients Included in Respiratory Failure Series

\begin{tabular}{|c|c|c|c|}
\hline No. & Age & Sex & Diagnosis \\
\hline 1 & 72 & M & $\begin{array}{l}\text { head injury; burr holes for subdural } \\
\text { haematoma; G.I. bleeding; aspiration }\end{array}$ \\
\hline 2 & 39 & $\mathbf{M}$ & bronchial asthma; pneumonia \\
\hline 3 & 68 & M & $\begin{array}{l}\text { myasthenia gravis; chronic bronchitis; } \\
\text { cholecystectomy }\end{array}$ \\
\hline 4 & 51 & $\mathbf{M}$ & $\begin{array}{l}\text { crushed chest; compound fracture of } \\
\text { tibia }\end{array}$ \\
\hline $\mathbf{5}$ & 37 & M & crushed chest; contusion to kidney \\
\hline 6 & 22 & $\mathbf{F}$ & myasthenia gravis; thymectomy \\
\hline 7 & 27 & $\mathrm{M}$ & $\begin{array}{l}\text { drug overdosage (Doridon }{ }^{\otimes} \text { and } \\
\text { Stelazine }{ }^{\otimes} \text { ); pulmonary oedema }\end{array}$ \\
\hline $\begin{array}{l}8 \\
9\end{array}$ & $\begin{array}{l}63 \\
22\end{array}$ & $\mathrm{M}$ & $\begin{array}{l}\text { emphysema; right heart failure } \\
\text { drug overdosage (Doridon }{ }^{\Theta} \text { ) }\end{array}$ \\
\hline 10 & 63 & M & $\begin{array}{l}\text { drug overdosage (Doridon }{ }^{6} \text { ) } \\
\text { G.I. bleeding; ligation oesophageal } \\
\text { varices; mediastinitis; emphysema }\end{array}$ \\
\hline 11 & 63 & $\mathbf{M}$ & emphysema; bronchopneumonia \\
\hline 12 & 20 & $\mathbf{M}$ & chest injury; head injury \\
\hline
\end{tabular}

FRC and $\mathrm{AaDO}_{2}$ during respiratory failure

Except in the two patients who died, in every case the final FRC was greater than that measured on admission in respiratory failure (Fig. 1, Table II). A low FRC and a large oxygen gradient were common at the time of admission. In most cases an increase in FRC was associated with an improvement in oxygenation (Fig. 2, Table II), although this was not a constant observation.

The FRC measured at the croc was in most cases higher than that measured when breathing 100 per cent oxygen (Fig. 3, Table II). However, the difference in FRC as measured at the two different oxygen concentrations was usually not large.

While the data indicate the relationship between the oxygen gradient and FRC in each instance, values were not collected at sufficiently constant intervals or in sufficient numbers to permit comment on the time course of the changes observed.

\section{Discussion}

The low resting lung volumes observed in patients in respiratory failure may be due to a variety of mechanisms such as atelectasis from airway obstruction by 


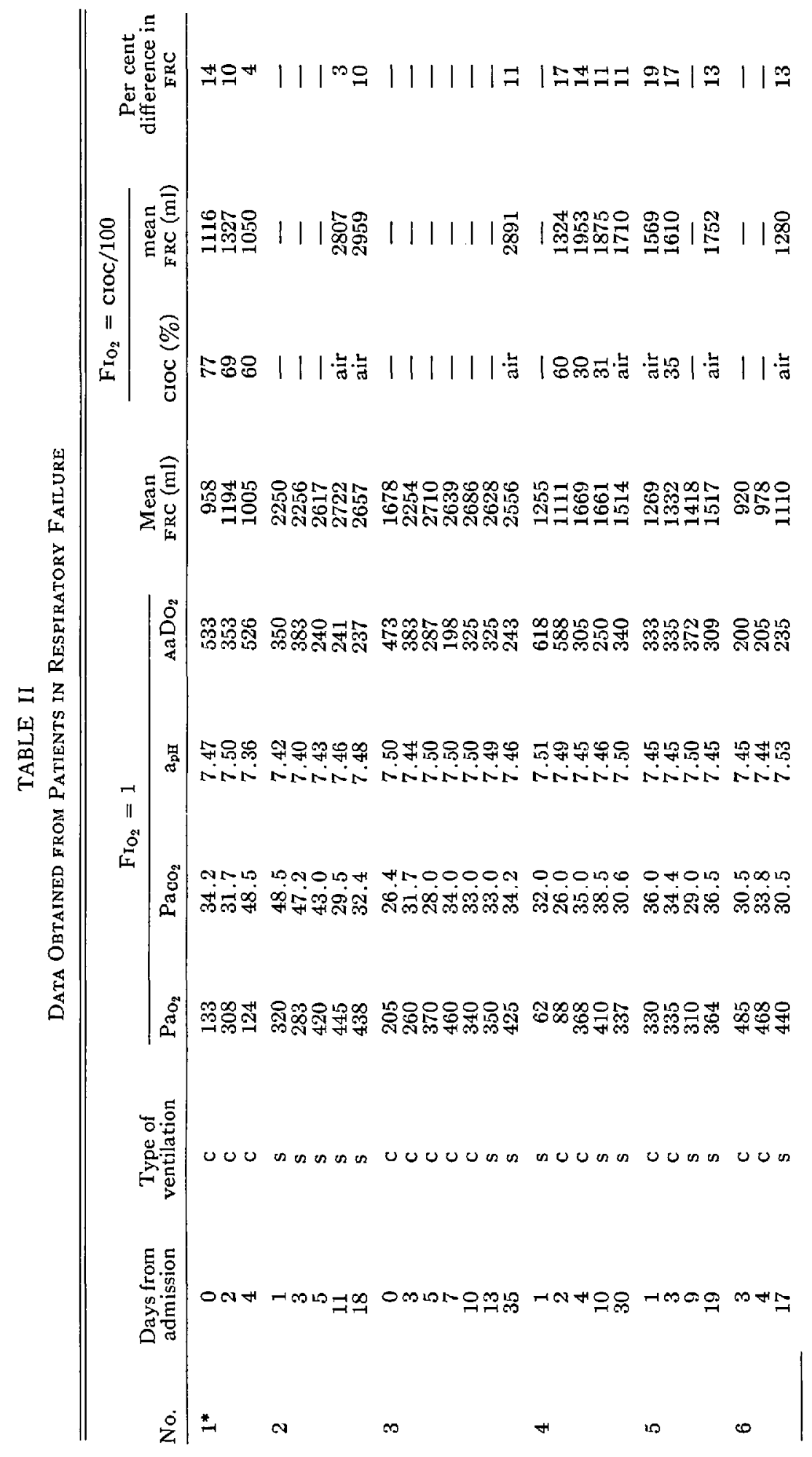




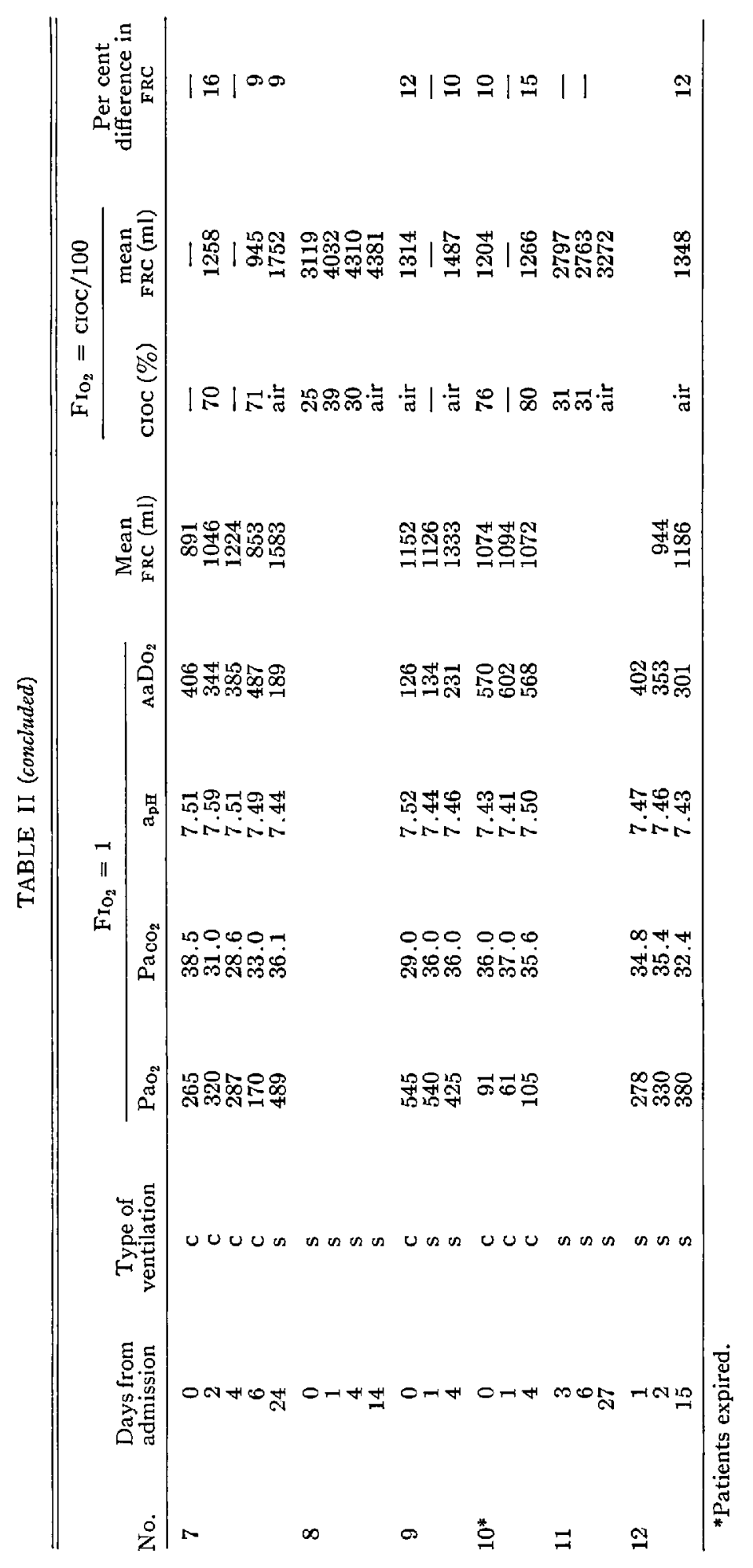


TABLE III

EfFect of Recumbency on frc in Normal Subjects

\begin{tabular}{|c|c|c|c|c|c|c|c|c|}
\hline & \multirow[b]{2}{*}{ Age } & \multirow{2}{*}{$\begin{array}{c}\text { Surface } \\
\text { area } \\
\left(\mathrm{m}^{2}\right)\end{array}$} & \multicolumn{2}{|c|}{ FRC sitting } & \multicolumn{2}{|c|}{ FRC recumbent } & \multicolumn{2}{|c|}{ Fall in FRC } \\
\hline & & & $\mathrm{ml}$ & $\mathrm{ml} / \mathrm{m}^{2}$ & $\mathrm{ml}$ & $\mathrm{ml} / \mathrm{m}^{2}$ & $\mathrm{ml}$ & $\mathrm{ml} / \mathrm{m}^{2}$ \\
\hline $\begin{array}{c}\text { Males } \\
1 \\
2 \\
3 \\
4 \\
5 \\
6 \\
7 \\
8 \\
9 \\
10 \\
11 \\
12 \\
13 \\
14\end{array}$ & $\begin{array}{l}26 \\
32 \\
36 \\
28 \\
25 \\
43 \\
40 \\
43 \\
33 \\
44 \\
57 \\
23 \\
37 \\
49\end{array}$ & $\begin{array}{l}1.71 \\
1.74 \\
1.91 \\
1.75 \\
1.74 \\
1.94 \\
1.96 \\
2.0 \\
1.88 \\
1.95 \\
1.85 \\
1.80 \\
2.02 \\
1.62\end{array}$ & $\begin{array}{l}2252 \\
3261 \\
3270 \\
2304 \\
2647 \\
2241 \\
3336 \\
3130 \\
3289 \\
3225 \\
2522 \\
2135 \\
3509 \\
2186\end{array}$ & $\begin{array}{l}1492 \\
1874 \\
1712 \\
1317 \\
1521 \\
1155 \\
1702 \\
1565 \\
1749 \\
1654 \\
1363 \\
1185 \\
1595 \\
1349\end{array}$ & $\begin{array}{l}2177 \\
2102 \\
2224 \\
1060 \\
1631 \\
1569 \\
2618 \\
2317 \\
2112 \\
2025 \\
1940 \\
1416 \\
2522 \\
1270\end{array}$ & $\begin{array}{r}1293 \\
1208 \\
1164 \\
606 \\
937 \\
809 \\
1336 \\
1159 \\
1124 \\
1038 \\
1048 \\
786 \\
1146 \\
784\end{array}$ & $\begin{array}{r}375 \\
1159 \\
1049 \\
1244 \\
1016 \\
672 \\
718 \\
813 \\
1177 \\
1200 \\
582 \\
719 \\
987 \\
916\end{array}$ & $\begin{array}{l}219 \\
666 \\
548 \\
711 \\
584 \\
346 \\
366 \\
417 \\
626 \\
615 \\
315 \\
399 \\
449 \\
565\end{array}$ \\
\hline $\begin{array}{l}\text { Mean } \\
\text { s.D. }\end{array}$ & $\begin{array}{r}36.9 \\
9.8\end{array}$ & $\begin{array}{r}1.85 \\
.12\end{array}$ & $\begin{array}{r}2807.6 \\
521.0\end{array}$ & $\begin{array}{r}1516.6 \\
217.4\end{array}$ & $\begin{array}{r}1927 \\
469.8\end{array}$ & $\begin{array}{r}1031.3 \\
216.4\end{array}$ & $\begin{array}{l}901.7 \\
262.7\end{array}$ & $\begin{array}{l}487.6 \\
148.6\end{array}$ \\
\hline $\begin{array}{c}\text { Females } \\
1 \\
2 \\
3 \\
4 \\
5 \\
6 \\
7 \\
8 \\
9 \\
10\end{array}$ & $\begin{array}{l}23 \\
25 \\
23 \\
33 \\
25 \\
30 \\
36 \\
23 \\
50 \\
57\end{array}$ & $\begin{array}{l}1.69 \\
1.58 \\
1.60 \\
1.62 \\
1.72 \\
1.34 \\
1.58 \\
1.57 \\
1.81 \\
1.46\end{array}$ & $\begin{array}{l}2532 \\
2123 \\
1860 \\
2685 \\
2394 \\
1821 \\
2731 \\
2502 \\
2721 \\
2294\end{array}$ & $\begin{array}{l}1499 \\
1344 \\
1663 \\
1657 \\
1391 \\
1359 \\
1728 \\
1594 \\
1503 \\
1571\end{array}$ & $\begin{array}{l}2035 \\
1486 \\
1548 \\
1552 \\
1196 \\
1298 \\
1407 \\
1439 \\
1546 \\
1104\end{array}$ & $\begin{array}{r}1204 \\
941 \\
968 \\
958 \\
695 \\
969 \\
891 \\
917 \\
854 \\
756\end{array}$ & $\begin{array}{r}497 \\
637 \\
312 \\
1133 \\
1198 \\
523 \\
1324 \\
1063 \\
1175 \\
1190\end{array}$ & $\begin{array}{l}294 \\
403 \\
195 \\
699 \\
697 \\
390 \\
838 \\
677 \\
649 \\
815\end{array}$ \\
\hline $\begin{array}{l}\text { Mean } \\
\text { s.D. }\end{array}$ & $\begin{array}{l}32.5 \\
12.06\end{array}$ & $\begin{array}{r}1.58 \\
.13\end{array}$ & $\begin{array}{r}2366.3 \\
337.0\end{array}$ & $\begin{array}{c}1480.9 \\
168.83\end{array}$ & $\begin{array}{c}1461.1 \\
254\end{array}$ & $\begin{array}{l}915.3 \\
137.3\end{array}$ & $\begin{array}{l}905.2 \\
369.4\end{array}$ & $\begin{array}{l}565.7 \\
225.9\end{array}$ \\
\hline
\end{tabular}

secretions or compression of lung tissue, pneumonic consolidation, pulmonary contusion, and pulmonary oedema. In addition to acute pulmonary disease, extrapulmonary factors may also contribute to low initial resting lung volumes. These include pleural effusion, abdominal distention, obesity, instability of the chest wall, and muscle weakness. Thus, the improvement of resting lung volume in response to appropriate therapy may be quite rapid when the aetiological factor is corrected quickly, as in cases of acute pulmonary oedema or pleural effusion, and slower in cases of lesions corrected more slowly, such as chest injuries (Table II).

The improvement in the oxygen gradient, coincident with an increase in lung volume, suggests that the increase in FRC was probably due to the opening up of previously non-ventilated alveoli.

Since many of the values of FRC observed in patients with respiratory failure were unusually low, normal values under similar circumstances of posture and inspired oxygen mixture were examined. The fall in FRC observed when these subjects assume the supine position is comparable to that reported previously. ${ }^{7-9}$ This fall has been attributed to an elevation of the diaphragm and an increase in the pulmonary blood volume. 
RAMACHANDRAN \& FAIRLEY: FRC DURING RESPIRATORY FAILURE

TABLE IV

Effect of Four Hours of Recumbency on frc in Normal Subjects

\begin{tabular}{|c|c|c|c|c|c|c|c|c|c|}
\hline \multirow[b]{2}{*}{ No. } & \multirow[b]{2}{*}{ Sex } & \multirow[b]{2}{*}{ Age } & \multirow{2}{*}{$\begin{array}{l}\text { Sitting } \\
(\mathrm{ml})\end{array}$} & \multirow{2}{*}{$\begin{array}{c}\text { Supine } \\
\text { (ml) }\end{array}$} & & \multicolumn{4}{|c|}{ Supine (ml) } \\
\hline & & & & & & 1 hour & 2 hours & 3 hours & 4 hours \\
\hline 1 & $\mathbf{M}$ & 40 & 3255 & 2318 & & 2594 & 2449 & 2227 & 2374 \\
\hline 2 & M & 32 & 2554 & 1468 & & 2152 & 2093 & 2147 & 2108 \\
\hline 3 & $\mathbf{M}$ & 23 & 2135 & 1185 & & 1585 & 1515 & 1322 & 1401 \\
\hline 4 & $M$ & 37 & 3509 & 1595 & & 2774 & 2451 & 2533 & 2593 \\
\hline 5 & M & 49 & 2186 & 1349 & & 1250 & 1137 & 1103 & 1255 \\
\hline 6 & M & 26 & 2847 & 2113 & & 2025 & 2049 & 2018 & 2008 \\
\hline \multicolumn{2}{|c|}{$\begin{array}{l}\text { Mean difference } \\
\text { S.D. } \\
p\end{array}$} & & \multicolumn{2}{|c|}{$\begin{array}{r}+1076.33 \\
426.99 \\
.01\end{array}$} & $\begin{array}{c}-392.0 \\
487.77 \\
.1\end{array}$ & & $\begin{array}{l}.33 \\
.17 \\
.05\end{array}$ & $\begin{array}{l}.33 \\
.35 \\
.3\end{array}$ & $\begin{array}{l}.83 \\
.682 \\
.05\end{array}$ \\
\hline
\end{tabular}

TABLE V

Effect of Change in Inspired Oxygen Concentration on fre in Normal Subjects

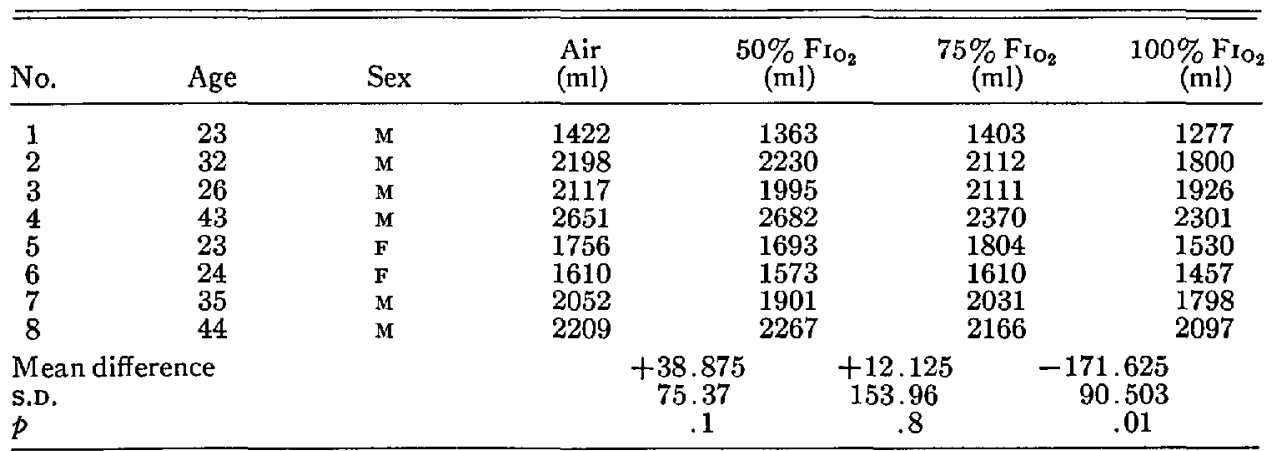

Changes in lung volumes secondary to oxygen breathing have been studied by several authors. Déry et al. ${ }^{10}$ demonstrated that FRC did not fall when the inspired gas contained at least 50 per cent nitrogen. Dubois et al. ${ }^{15}$ showed that a fall in vital capacity with oxygen breathing could be prevented if the inspired gas contained at least 5 per cent nitrogen. The fall in FRC in relation to oxygen breathing was noted in this series only when the subjects breathed 100 per cent oxygen and was not observed when 50 or 75 per cent oxygen was breathed. This fall in FRC was in most cases not very large. As most of the patients in respiratory failure were breathing inspired gas mixtures containing less than 75 per cent oxygen when the measurements were made at the croc, the inspired oxygen concentration by itself probably does not explain the low FrC. Further, the increase in volume observed during the course of the patient's hospital stay suggests the presence of an additional reversible component. In these cases, therapy aimed at alveolar expansion would be justified as a part of each patient's therapeutic regimen. Such therapy would depend upon the underlying disease but might include treatment of pulmonary oedema, pleural effusion and abdominal distention, intermittent positive pressure ventilation with large tidal volumes, reversal of muscle weakness in patients with myasthenia gravis, chest physiotherapy and tracheobronchial 


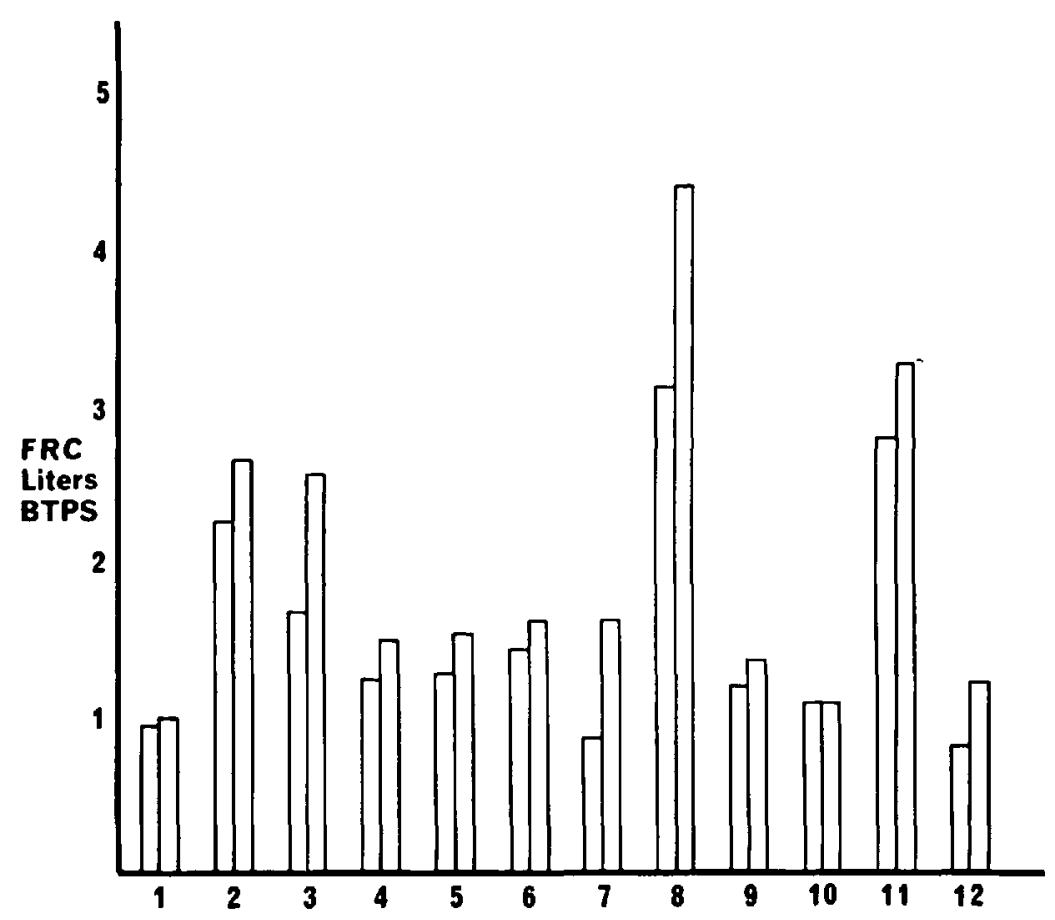

Ficure 1. First and last values of Fro obtained in each of 12 patients studied. Initial values are to the left in each instance.

toilet, minimizing the duration of exposure to soluble gases such as 100 per cent oxygen, and the application of a positive pressure expiratory plateau. ${ }^{16}$

A distinction between a fall in FRC due to recumbency and denitrogenation and that due to disease is further prompted by the frequent finding that the supine position produces only a modest increase in alveolar-arterial oxygen difference in normal persons, ${ }^{17-19}$ as opposed to the very high values seen in several of the patients presented here. Presumably, the fall in FRC associated with recumbency and denitrogenation is due to collapse of alveoli which cease to be perfused, or to factors other than alveolar collapse. Mead ${ }^{20}$ states that the lower limits of alveolar volume are determined by the interactions of the surface tension forces and the capacity of the inspiratory muscles to develop inflating pressures. It is possible that many patients in respiratory failure demonstrate evidence of alveolar collapse because of an inability to develop inflating pressures, or because when a sufficient pressure is developed it is not transmitted to some alveoli because of airway obstruction from mucus, oedema fluid, or compression.

There is insufficient data from this series on which to base firm conclusions as to the usefulness of the FRC in the management of patients with respiratory failure. However, it is clear that resting lung volume may be extremely low, and, unless this is due to reversible atelectasis or pulmonary oedema, it may be unwise to ventilate such patients with large tidal volumes calculated on a body weight basis.

In most instances $\mathrm{AaDo}_{2}$ and $\mathrm{FRC}$ show an inverse relationship, and knowledge 


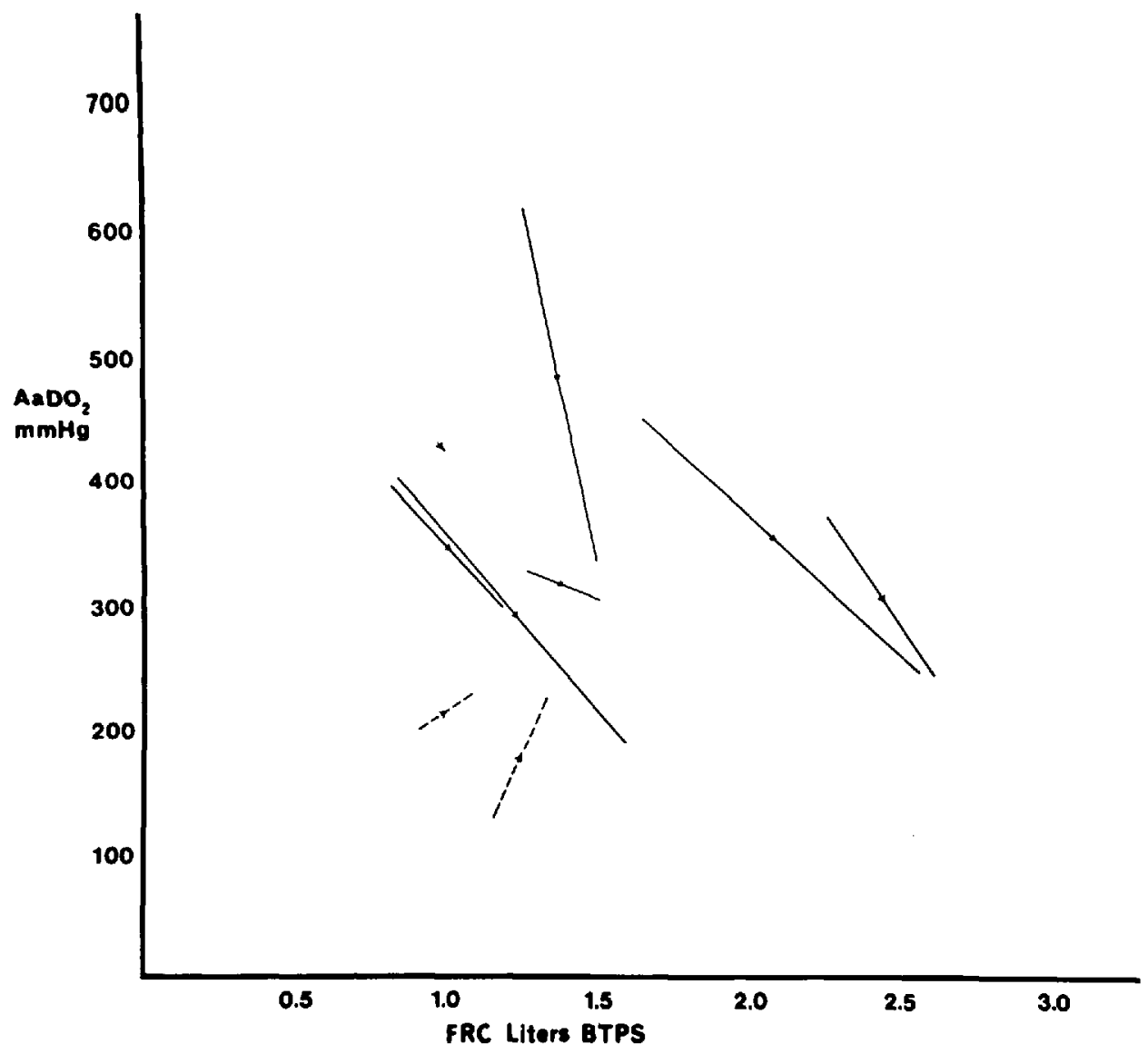

FIGURE 2. Lines joining first and last values of FRC and $\mathrm{AaDo}_{2}$ obtained in patients with respiratory failure. Dotted lines are from the patients whose frcs went up but whose oxygen gradients increased after they came off the ventilator.

of lung volume probably adds little to routine clinical management, when inspired and arterial oxygen tensions are readily available and pressure-volume relationships can be followed.

\section{SuMmary}

Changes in functional residual capacity and their relationship to alveolararterial oxygen difference were observed during the course of respiratory failure in twelve patients. The influence of recumbency and oxygen breathing on FRC in normal subjects was also examined.

Low resting lung volumes and large alveolar-arterial oxygen differences were often observed at the time of admission in respiratory failure. The reduction in FRC cannot be explained on the basis that these measurements were made in recumbent patients breathing a high concentration of oxygen in the inspired gas.

An increase in FRC was often associated with an improvement in oxygenation, and it is inferred that in these patients correction of FRC is associated with the opening up of previously non-ventilated alveoli, and that therapy designed with 


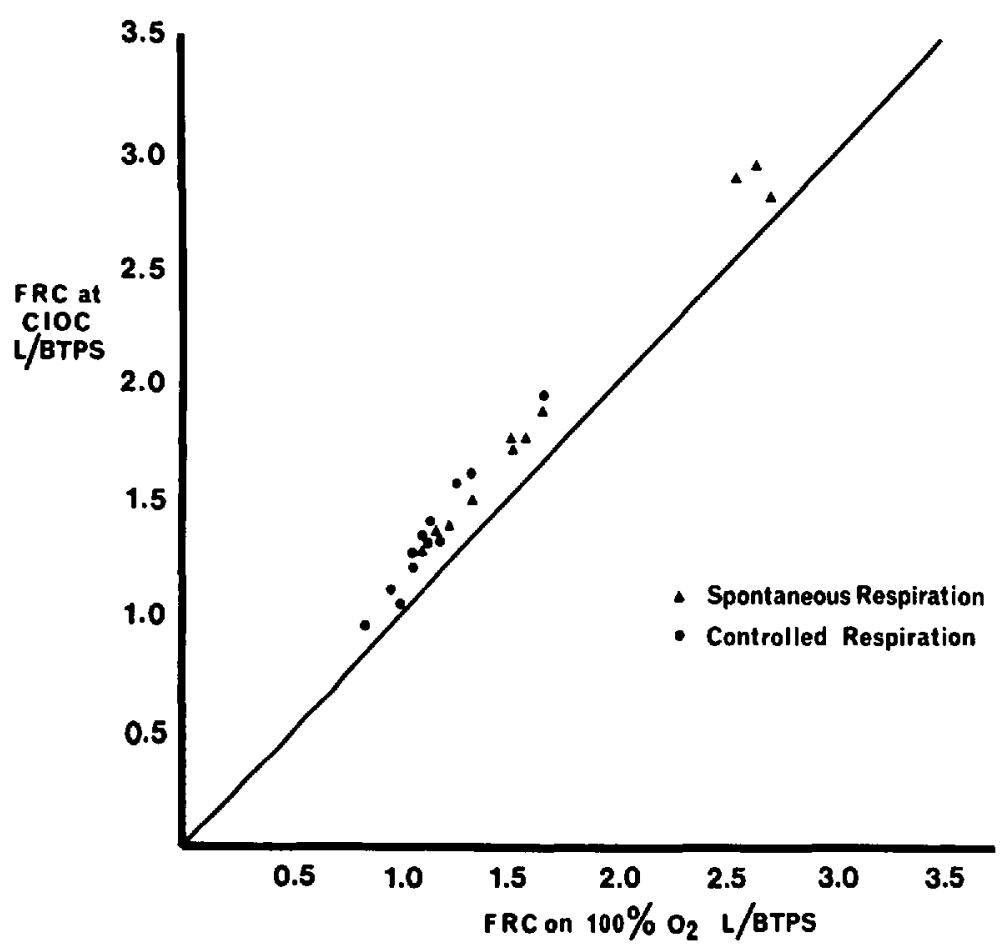

Figure 3. Comparison of values for FRC: breathing clinically indicated oxygen concentration and breathing 100 per cent oxygen.

this objective is therefore justified. However, when extremely low resting lung volume is due to causes not reversible mechanically, such as diffuse pneumonia, large tidal volume ventilation determined on a body weight basis may not be indicated. Measurement of FRC is not recommended for routine clinical management.

\section{RÉSUMÉ}

$\mathrm{Au}$ cours de linsuffisance respiratoire survenue chez 12 malades, nous avons réussi à observer les modifications de la capacité résiduelle fonctionnelle et leur relation avec la différence en oxygène alvéolaire et artérielle. Nous avons également étudié chez des sujets normaux les effets du décubitus et de la ventilation à l’oxygène sur la capacité fonctionnelle résiduelle.

Au moment de l'admission pour insuffisance respiratoire, nous avons noté des volumes pulmonaires restreints au repos et de grandes différences en oxygène alvéolaire et artérielle. La diminution de la capacité fonctionnelle résiduelle ne s'applique pas par le fait que ces mesures ont été faites sur des malades en décubitus et respirant une atmosphère à haute concentration en oxygène.

Une augmentation de la capacité fonctionnelle résiduelle a souvent été accompagnée d'une amélioration de l'oxygénation et l'on conclut que, chez ces malades, la correction de la capacité fonctionnelle résiduelle s'accompagne de l'ouverture d'alvéoles non ventilées antérieurement et qu'ainsi, la thérapie préconisée dans ce but devient alors justifiée. Toutefois, lorsque de très petits vo- 
lumes respiratoires au repos sont dus à des causes impossibles à vaincre mécaniquement, comme une pneumonie diffuse, il peut ne pas être indiqué de faire une ventilation à grand volume d'air courant calculée d'après le poids du malade. Nous ne recommandons pas le calcul de la capacité fonctionnelle résiduelle comme conduite clinique de routine.

\section{REFERENCES}

1. Bendixen, H. H.; Hedley-Whyte, J.; \& LAver, M. B. Impaired Oxygenation in Surgical Patients during General Anesthesia with Controlled Ventilation. New England J. Med. 260: 991 (1963).

2. Hedley-Whyte, J.; Pontoppidan, H.; \& Jocelyn Morris, M. The Response of Patient with Respiratory Failure and Cardio-pulmonary Disease to Different Levels of Constant Volume Ventilation. J. Clin. Invest. 34: 1005 (1955).

3. Pontoppman, H.; Hedley-Whyte, J.; Bendixen, H. H.; Laver, M. B.; \& Radford, E. P. Jr. Ventilation and Oxygen Requirements during Prolonged Artificial Ventilation in Patients with Respiratory Failure. New England J. Med. 273: 401 (1963).

4. Laver, M. B.; Morgan, J.; Bendixen, H. H.; \& Radford, E. P. Jr. Lung Volume, Compliance and Arterial Oxygen Tensions during Controlled Ventilation. J. Appl. Physiol. 19: 725 (1964).

5. Colgan, F. J.; Whang, T. B.; \& Gulies, A. J. Atelectasis and Pneumothorax. Anesthesiology. 29: 923 (1968).

6. BEECHER, H. K. Effect of Laparotomy on Lung Volume: Demonstration of a New Type of Pulmonary Collapse. J. Clin. Invest. 12: 651 (1933).

7. Huertado, A. \& Fray, W. W. Studies of Total Pulmonary Capacity and Its Subdivisions: III. Changes with Body Posture. J. Clin. Invest. 12: 825 (1933).

8. Whitfield, A. G. W.; Waterhouse, A. J. H.; \& Arnott, W. The Total Lung Volume and Its Subdivisions: A Study in Physiological Norms. I. Basic Data. Brit. J. Social Med. 4 (1950).

9. LIN, T. P. K. \& LEIFT, V. C. Alterations in Lung Compliance and Functional Residual Capacity with Posture. J. Appl. Physiol. 14: 164 (1959).

10. Déry, R.; Pelletier, J.; Jacques, A.; Clavet, M.; \& Houde, J. Alveolar Collapse Induced by Denitrogenation. Canad. Anaesth. Soc. J. 12: 531 (1965).

11. Meneely, G. R.; Ball, C. O. T.; Kory, R. C.; Galloway, J. J.; Mefrill, J. M.; Mabe, R. E.; Roemm, D. C.; \& Kaltreider, N. L. A simplified Closed Circuit Helium Dilution Method for the Determination of the Residual Volume of the Lungs. Am. J. Med. 29: $824(1960)$.

12. Colgan, F. J. \& Whanc, T. B. A Method for Measuring the Functional Residual Capacity and Dynamic Lung Compliance during Oxygen and Halothane Inhalation. Anesthesiology. 28: 559 (1967).

13. LAws, A. K. Effect of Induction of Anaesthesia and Muscle Paralysis on Functional Residual Capacity of the Lungs. Canad. Anaesth. Soc. J. 15: 325 (1968).

14. FaIrLey, H. B. \& Britt, B. A. The Adequacy of the Air-mix Control in Ventilators Operated from an Oxygen Source. C.M.A.J. 90: 1394 (1964).

15. Dubots, A. B.; Turams, T.; Mammar, R. E.; \& Nebrega, F. T. Pulmonary Atelectasis in Subjects Breathing Oxygen at Sea Level and at Simulated Altitude. J. Appl. Physiol. 21: 828 (1966).

16. McIntyre, R. W.; Laws, A. K.; \& Ramachandran, P. R. Positive Expiratory Pressure Plateau: Improved Gas Exchange during Mechanical Ventilation. Canad. Anaesth. Soc. J. 16: 477 (1969).

17. FinLEY, T. N. The Determination of Uneven Pulmonary Blood Flow from the Arterial Oxygen Tension during Nitrogen Washout. J. Clin. Invest. 40: 1727 (1961).

18. SAD, S. I. \& BENERGEE, C. M. Venous Admixture to the Pulmonary Circulation in Human Subjects Breathing 100\% Oxygen. J. Clin. Invest. 42: 597 (1963).

19. Morgan, E. A. \& Naras, G. G. Study of Relationship of Arterial Oxygen Tension to Alveolar Oxygen Pressure in Man Utilizing a Polarometric Method for Whole Blood (abstract). Am. J. Physiol. 163: 736 (1950).

20. MeAD, J. Mechanics of Respiratory Structures. In: Ciba Foundation Symposium on Pulmonary Structure and Function. London: Churchill III (1962). 